\title{
ISOLATION AND IDENTIFICATION OF LACTIC ACID BACTERIA IN WINTER SALAD (LOCAL PICKLE) DURING FERMENTATION USING 16S rRNA GENE SEQUENCE ANALYSIS
}

\author{
MANSOUR SAEEDI ${ }^{1}$, FAKHRI SHAHIDI ${ }^{1,3}$, SEYED ALI MORTAZAVI ${ }^{1}$, ELNAZ MILANI ${ }^{2}$ and \\ FARIDEH TABATABAEI YAZDI ${ }^{1}$ \\ 'Department of Food Science and Technology, Faculty of Agriculture, Ferdowsi University of Mashhad, Mashhad, Iran \\ ${ }^{2}$ Academic Center for Education, Culture and Research (ACECR) Mashhad- Iran
}

${ }^{3}$ Corresponding author.

TEL:+989155161428;

FAX: +985138787430;

EMAIL: f.shahidi@um.ac.ir

Received for Publication January 26, 2014 Accepted for Publication June 3, 2014

doi: $10.1111 / \mathrm{jfs} .12128$

\begin{abstract}
Winter salad is a kind of pickle made of different vegetables and is consumed specially in Khorasan Province. The spontaneous fermentation process is mainly carried out by lactic acid bacteria (LAB). The aim of this study was to isolate and identify the LAB species involved in winter salad fermentation at different fermentation time intervals to introduce the native strains. In order to classify selected isolates that seemed LAB, according to preliminary experiments, biochemical tests were performed. Forty-five selected isolate genotypically identified based on $16 \mathrm{~S}$ rRNA gene sequencing. The results show that the analysis with 16s rRNA gene sequencing could successfully identify eight species, including Pediococcus (51.1\%), Lactobacillus (26.7\%), Weissella (11.1\%), Enterococcus (6.7\%) and Leuconostoc (4.4\%). Although Weissella cibaria and Lactobacillus plantarum were the predominant LAB in the early periods of winter salad fermentation, Pediococcus pentosaceus was the predominant $\mathrm{LAB}$ at the later periods.
\end{abstract}

\section{PRACTICAL APPLICATIONS}

Fermented vegetables are usually used as seasoning in Iran. To our knowledge, this is the first study to examine fermented vegetables lactic acid flora using molecular methods, in Iran. Indigenous starter bacteria are normally considered as genetic resources, and strains obtained from this study could be used in the industry and some of them may be considered as probiotic strains.

\section{INTRODUCTION}

Lactic acid bacteria (LAB) constitute a group of grampositive, nonsporing, nonrespiring cocci or rods, which produce lactic acid as the major end product during the fermentation of carbohydrates. From food technology point of view, the following genera are considered the principal LAB: Aerococcus, Carnobacterium, Enterococcus, Lactobacillus, Lactococcus, Leuconostoc, Oenococcus, Pediococcus, Streptococcus, Tetragenococcus, Vagococcus and Weissella (Axelsson 2004). The spontaneous fermentation of food has been utilized for more than 5,000 years by mankind. It involves different products such as dairy products such as cheese, yoghurt and kefir; meat products such as salami or ham; and vegetable products such as sauerkraut or olives (Geisen and Holzapfel 1996).

Fermented vegetable foods are culturally and economically important, and their suitability in remote developing areas has made them an important component of the millions of people's diet. Therefore, they have a worldwide interest because of their sensory properties, their extended shelf life and as carriers of probiotic bacteria such as LAB (Abriouel et al. 2012). Most of the LAB involved in spontaneous fermentation of vegetables are Lactobacillus spp. (Lactobacillus plantarum, La.fermentum), Leuconostoc spp. (Le. mesenteroides), Pediococcus spp. (P. pentosaceus, 


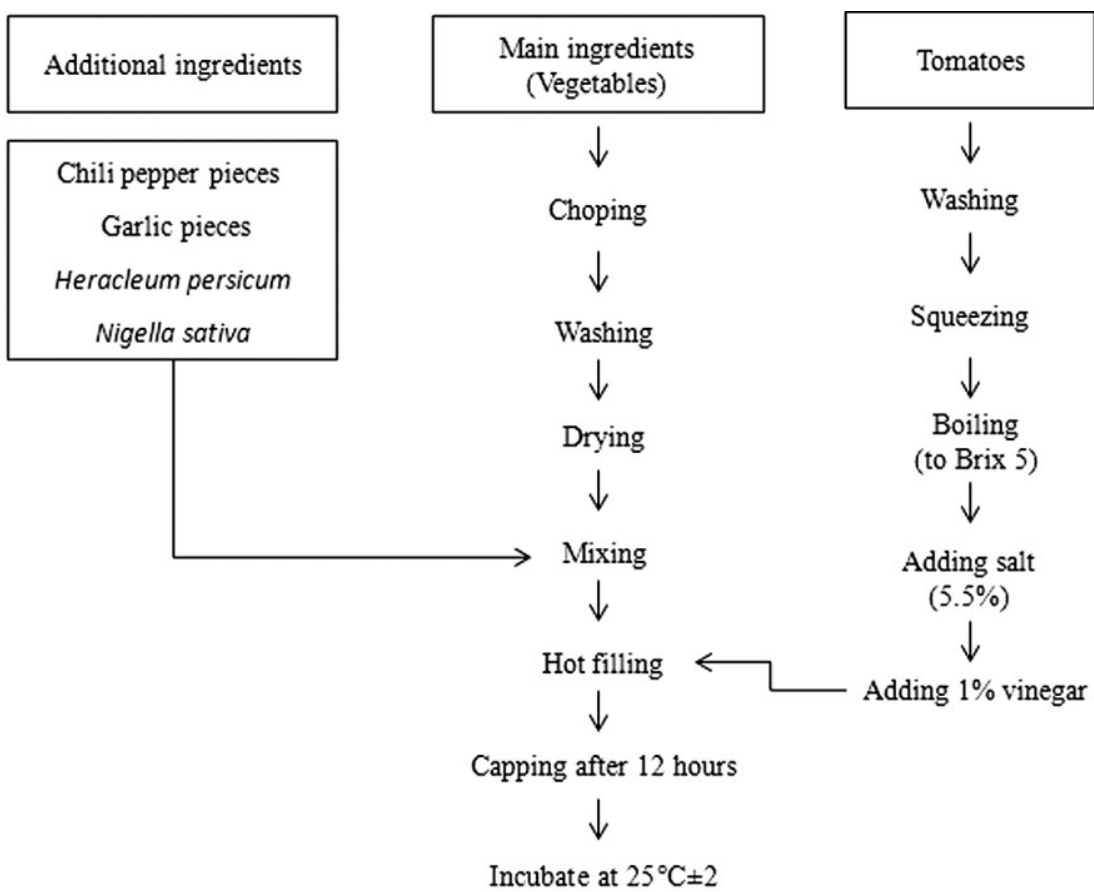

FIG. 1. FLOW DIAGRAM FOR WINTER SALAD PRODUCTION
P. acidilactici) and Weissella spp. (W. cibaria, W. koreensis) (Kim and Chun 2004; Perez Pulido et al. 2005; Tamang et al. 2005; Chen et al. 2010; Emerenini et al. 2013).

Like many Middle Eastern countries, Iran has a long tradition in producing several types of fermented vegetable products that are frequently used as seasoning in Iran. In fact, winter salad is a kind of pickle made of different vegetables and is consumed specially in Khorasan Province. An overview of the production of winter salad is shown in Fig. 1.

The polymerase chain reaction (PCR)-based methods are useful to identifying bacteria as a complementary or alternative tool to phenotypical methods. Over the years, identification methodologies use primers that target different sequences, such as the $16 \mathrm{~S}$ ribosomal RNA encoding gene, the 16S-23S rRNA intergenic spacer region and the 23S rRNA encoding (Mohania et al. 2008). Today, the bacterial $16 \mathrm{~S}$ ribosomal RNA operon, encompassing 16S rRNA and $23 \mathrm{~S}$ rRNA genes, is the most frequently used as a molecular marker in microbial ecology because of a number of reasons including: (1) its evolutionary and phylogenetic properties, reflected by the presence of both variable and highly conserved sequence domains; (2) its high discriminatory potential; and (3) the extensive availability of sequences in public databases (Juste et al. 2008). Several studies have been carried out on the $\mathrm{LAB}$ composition of various vegetables, using 16S rRNA gene sequence analysis and phenotypic identification (Tamang et al. 2007; Park et al. 2010; Patil et al. 2010; Pang et al. 2011).

In this study, the profile of microbiological biodiversity and physicochemical changes of winter salad samples during the fermentation interval times $(0,7,14,21$ and 28 days) were evaluated. Lactic acid flora of winter salad was studied by the classical culturing method and also by molecular analysis-based $16 \mathrm{~S}$ rRNA gene sequence analysis.

\section{MATERIALS AND METHODS}

\section{Production of Winter Salad}

The vegetables (cabbage, carrot, pepper, garlic, cauliflower, Jerusalem artichoke and celery) used for the production of winter salad were purchased from local markets in Mashhad, Iran. According to the traditional production instruction of Winter salad the vegetables, were chopped and washed with fresh water and then were dried for $30 \mathrm{~min}$. The vegetables were pooled and placed in $250 \mathrm{~g}$ jars; a few pieces of chili peppers and garlic with a little Heracleum persicum (golpar) and Nigella sativa seeds were also added to each jar. Then the jars were filled with tomato juice (Brix 5) and 5.5\% (w/w) edible salt. In order to acidification, $1 \%$ of vinegar was added to tomato juice. Forty-five jars were produced and after $12 \mathrm{~h}$ the jar lids were tightly closed. Samples were stored at room temperature $25 \pm 2 \mathrm{C}$.

\section{Sampling}

As ripening period of winter salad is 3 weeks, the sampling was performed in five 7-day intervals (day 0 , day 7 , day 14 and day 21) and day 28 as after ripening period. Sampling was performed from six jars per day and winter salad LAB 
isolated and enumerated in Man Rogosa Sharpe agar aerobically and anaerobically in mentioned time intervals. Ten grams of sample was homogenized in a Stomacher (400; Seward, Worthing, UK), with $90 \mathrm{~mL}$ of $0.85 \% \mathrm{w} / \mathrm{v}$ sterile physiological saline for $5 \mathrm{~min}$ and serially diluted $\left(10^{-1}\right.$ to $\left.10^{-8}\right)$. One hundred microliters of these dilutions was pour plated in the MRS agar (Merck, Darmstadt, Germany). LAB were detected and isolated on MRS agar after incubation under both aerobic and anaerobic conditions in an anaerobic gas pack system (Merck) at 25, 37 and 45C for 48-72 h. Distribution of mesophilic and thermophilic LAB in the samples was investigated using three different incubation temperatures: 45C for thermophilic $\mathrm{LAB}$ and 25 and $37 \mathrm{C}$ for mesophilic ones in three replicates for each temperature. Purity of the isolates was checked by streaking again and subculturing on fresh agar plates of the isolation media. Purified strains of LAB were preserved in MRS broth using $15 \% \mathrm{v} / \mathrm{v}$ glycerol at $-80 \mathrm{C}$ (Tamang et al. 2005).

\section{pH and Titratable Acidity}

Ten grams of each sample was blended with $20 \mathrm{~mL}$ of distilled water, $\mathrm{pH}$ was determined directly using a digital $\mathrm{pH}$ meter (Metrohm $744 \mathrm{pH}$ meter, Herisau, Switzerland). Titratable acidity was determined by titrating brine up to pH 8.2 with $0.1 \mathrm{~N} \mathrm{NaOH}$ and expressed as grams of lactic acid per $100 \mathrm{~mL}$ brine (Panagou et al. 2008).

\section{Morphological, Physiological and Biochemical Tests}

Overnight cultures of LAB isolates were Gram stained, and cell morphology of all strains of LAB was determined in a phase contrast microscope (Olympus BX41-TF, Tokyo, Japan). Catalase test was carried out by adding few drops of freshly prepared $3 \%$ hydrogen peroxide to each plate containing 18-hour-old culture of each isolate. In order to classify 136 selected isolates that according to preliminary experiments seemed to be $\mathrm{LAB}$, biochemical tests include carbon dioxide production from glucose, growth at 10 and $45 \mathrm{C}$, growth at $6.5 \% \mathrm{NaCl}$, growth at $\mathrm{pH}=4.4$ and $\mathrm{pH}=9.6$, and hydrolysis of arginine was performed (Schillinger and Lucke 1987; Dykes et al. 1994). Carbohydrate fermentation tests were performed in Phenol Red Broth base (Quelab, Dandurand, Montreal, QC, Canada) with $1 \%$ mannitol, sorbitol, maltose, fructose, melibiose, sucrose, galactose, raffinose, glucose and lactose (Merck) (Faklam and Collins 1998).

\section{DNA Extraction}

Fifty isolates were selected for molecular identification. Total genomic DNA was extracted from $0.1 \mathrm{~mL}$ sample of overnight cultures grown in MRS broth, with a Genomic DNA isolation kit (Dena Zist Asia, Mashhad, Iran).

\section{PCR Amplification of 16S rRNA Gene and Electrophoresis}

The universal primer pair consisted of the forward ( $5^{\prime} \mathrm{GAG}$ AGT TTG ATC CTG GCT CAG $3^{\prime}$ ) and reverse (5' GAA AGG AGG TGA TCC AGC CG $3^{\prime}$ ), which were used for amplification of $16 \mathrm{~S}$ rDNA that were obtained from Fermentase (Burlington, ON, Canada). Deoxyribonucleic acid amplification of the $(\sim 1,500$ bases $)$ fragment was carried out in a $20 \mu \mathrm{L}$ reaction mixture containing $2.5 \mu \mathrm{L}$ of $10 \times$ PCR buffer, $1 \mu \mathrm{L}$ deoxynucleoside triphosphate mixture $(10 \mathrm{mM}), 1.2 \mu \mathrm{L}$ of $\mathrm{MgCl} 2(25 \mathrm{mM}), 1 \mu \mathrm{L}$ of each primer $(100 \mathrm{pmol} / \mu \mathrm{L}), 3 \mu \mathrm{L}$ of DNA $(10 \mathrm{ng})$ and $0.3 \mu \mathrm{L}$ of Taq DNA polymerase $(5 \mathrm{U} / \mu \mathrm{L})$. All PCR chemicals were obtained from Cinnagen (Tehran, Iran). Amplification was performed in a SensoQuest Labcycler (D-37085, Goettingen, Germany). The PCR conditions were as follows: initial denaturation of DNA for $5 \mathrm{~min}$ at $95 \mathrm{C}$, then 30 cycles of denaturation of DNA for $1 \mathrm{~min}$ at $94 \mathrm{C}$, annealing for $1 \mathrm{~min}$ at $53 \mathrm{C}$, extension for $2 \mathrm{~min}$ at $72 \mathrm{C}$ and final incubation for $5 \mathrm{~min}$ at $72 \mathrm{C}$. The PCR products were analyzed by electrophoresis on a $1.2 \%$ agarose gel stained with Green viewer (Fermentase) in $1 \mathrm{X}$ TBE buffer at $90 \mathrm{~V}$ for $45 \mathrm{~min}$. The sizes of DNA fragments were estimated using a standard $1 \mathrm{~kb}$ DNA ladder (Fermentase), and the gels were documented using the SSM-930 Vilber Lourmat gel documentation imaging (Eberhardzell, Deutschland) (Taheri et al. 2009). Then the PCR products were sent to Macrogen (Seoul, Korea) for purifying and sequencing. To determine the closest known relatives of the partial 16S rRNA gene sequences obtained, identification was performed in public data libraries (GenBank) using the Basic Local Alignment Search Tool (BLAST) (Park et al. 2010).

\section{Phylogenetic Analysis}

The sequences of 16S rRNA gene were edited using the Chromas Lite 2.1 (Technolysum, South Brisbane, Australia), CLC Main Workbench 5.5 program (QIAGEN, Boston, MA), Mega version 6.05 (MEGA, Tempe, AZ), SPSS version 16.0 (WinWrap, Nikoski, AK). The phylogenetic trees were constructed by neighbor-joining statistical method. Escherichia coli ECSC1 was used as an outgroup. In order to determine the stability of our phylogenetic tree, the sequence data were sampled 1,000 times for bootstrap analysis using Mega version 6.05 with 50\% cutoff (Chao et al. 2007; Park et al. 2010).

\section{Statistical Analysis}

The data of counting LAB, pH and acidity were analyzed using SPSS version 16.0. A single-factor analysis of variance 
TABLE 1. CHANGES IN PH, ACIDITY AND LACTIC ACID BACTERIA COUNTS OF WINTER SALAD \pm STANDARD DEVIATION (SD) DURING RIPENING PERIODS

\begin{tabular}{|c|c|c|c|c|c|c|c|c|}
\hline \multirow[b]{3}{*}{ Day } & \multirow[b]{3}{*}{$\mathrm{pH}$} & \multirow[b]{3}{*}{ Acidity (\%) } & \multicolumn{6}{|l|}{ Log cfu/g } \\
\hline & & & \multicolumn{3}{|l|}{ Aerobic } & \multicolumn{3}{|l|}{ Anaerobic } \\
\hline & & & $25 C$ & $37 C$ & $45 C$ & $25 C$ & $37 C$ & $45 C$ \\
\hline 0 & $4.19 \pm 0.04^{a}$ & $0.571 \pm 0.012^{\mathrm{a}}$ & $3.73 \pm 0.04^{a}$ & $4.07 \pm 0.02^{\mathrm{a}}$ & $2.36 \pm 0.07^{\mathrm{a}}$ & $3.96 \pm 0.08^{\mathrm{a}}$ & $4.18 \pm 0.14^{a}$ & $2.50 \pm 0.15^{a}$ \\
\hline 7 & $3.91 \pm 0.07^{b}$ & $0.898 \pm 0.061^{b}$ & $8.32 \pm 0.07^{b}$ & $8.56 \pm 0.15^{b}$ & $7.86 \pm 0.04^{b}$ & $8.45 \pm 0.12^{b}$ & $8.49 \pm 0.09^{b}$ & $7.59 \pm 0.07^{b}$ \\
\hline 14 & $3.87 \pm 0.05^{b}$ & $0.930 \pm 0.054^{b}$ & $8.91 \pm 0.09^{c}$ & $9.31 \pm 0.03^{c}$ & $8.57 \pm 0.02^{c}$ & $9.20 \pm 0.05^{c}$ & $9.36 \pm 0.02^{c}$ & $8.56 \pm 0.02^{c}$ \\
\hline 21 & $3.80 \pm 0.05^{b}$ & $1.084 \pm 0.022^{c}$ & $10.68 \pm 0.01^{d}$ & $10.88 \pm 0.06^{d}$ & $9.87 \pm 0.11^{d}$ & $10.81 \pm 0.03^{d}$ & $10.85 \pm 0.03^{d}$ & $10.08 \pm 0.19^{d}$ \\
\hline 28 & $3.62 \pm 0.02^{c}$ & $1.396 \pm 0.034^{d}$ & $8.87 \pm 0.02^{c}$ & $9.10 \pm 0.14^{c}$ & $8.60 \pm 0.09^{c}$ & $9.21 \pm 0.06^{c}$ & $9.50 \pm 0.12^{c}$ & $8.73 \pm 0.08^{c}$ \\
\hline
\end{tabular}

cfu, colony-forming unit.

was used to calculate the standard error of the mean of the treatments. For all tests, differences were considered significant at $P<0.01$. All experiments were performed in duplicate. Duncan multiple range tests with a confidence interval of $99 \%$ were used to compare the means.

\section{RESULTS AND DISCUSSION}

\section{LAB Counts, pH and Acidity during Winter Salad Fermentation}

Acidity, $\mathrm{pH}$ and $\mathrm{LAB}$ counts of winter salad are shown in Table 1. The initial count of LAB at the start of fermentation (day 0), immediately after production, was low. In 25C, the $\mathrm{LAB}$ numbers exceed $4.15 \log$ colony-forming unit $(\mathrm{cfu}) / \mathrm{g}$ in $37 \mathrm{C}, 3.84 \mathrm{log} \mathrm{cfu} / \mathrm{g}$ in $45 \mathrm{C}$ and $2.43 \mathrm{log} \mathrm{cfu} / \mathrm{g}$. After 7 days LAB counts had grown at all three temperatures and were almost doubled. During fermentation on days 14 and 21 , this growth continued until near $10.5 \log \mathrm{cfu} / \mathrm{g}$. Ripening period of winter salad is 3 weeks and usually after this period, the product could be consumed. On day 28 after ripening period, LAB counts showed a decreasing trend probably reflecting beginning nutrient shortage. Decline in LAB counts was seen and it was near $9 \log \mathrm{cfu} / \mathrm{g}$. As it is clear, various stages of fermentation had significant effect on LAB count grown on MRS agar medium except days 14 and 28 at all three temperatures $(P<0.01)$.

The initial $\mathrm{pH}$ of winter salad on day 0 was 4.19 , and titratable acidity based on lactic acid was $0.571 \%$ due to tomato juice in formulation. On day 0 and day $28, \mathrm{pH}$ was significantly different from the other days $(P<0.01)$. During the fermentation of products, continuous decline in $\mathrm{pH}$ and increase in acidity was observed consistently. It shows that increasing the fermentation time causes higher lactic acid content in the product until day 21. But the highest acidity and the lowest $\mathrm{pH}$ were on day 28 . Decrease in $\mathrm{pH}$ and increase in acidity despite the reduction in the number of bacteria on day 28 may be due to the high potential of acidification of predominant LAB in this period.
There was significant difference in acidity at various days except on days 7 and $14(P<0.01)$.

\section{Identification}

One hundred and thirty-six gram-positive, catalase-negative isolates were obtained from various periods during winter salad fermentation. To classify that the isolates of LAB strains were phenotypically characterized on the basis of cell morphology, gas production from glucose, arginine hydrolysis, growth at different temperatures and $\mathrm{pH}$, the sugar fermentation patterns were determined (Table 2). All isolates based on physiological and biochemical characteristics were divided into 10 groups. Fifty isolates from 136 isolates were selected from these groups for genotypical characterization by $16 \mathrm{~S}$ rRNA gene sequence analysis. The isolates were chosen that contains all ten groups and all various ripening stages. After comparing 16S rRNA gene sequences obtained, with available sequences in database using the BLAST, 45 isolates that had high similarity (97\% and more) were selected (Table 3 ). The results of this study showed that the analysis with $16 \mathrm{~S}$ rRNA gene sequencing could be successfully identified in eight species, including P. pentosaceus (51.1\%), La. plantarum (20\%), W. cibaria (11.1\%), La.fermentum (6.7\%), Enterococcus faecium (4.4\%), En. faecalis (2.2\%), Leuconostoc citreum (2.2\%) and Leuconostoc mesenteroides subsp. mesenteroides (2.2\%).

Isolate series A was obtained from winter salad immediately after production. In conclusion, W. cibaria, Le. citreum, La. plantarum and P. pentosaceus were detected in the raw materials where W. cibaria was the dominant species. Weissella species are widespread in the natural environment. $W$. cibaria has been found in fermented foods (cassava, sourdough and the Japanese alcoholic beverage shochu) (Chao et al. 2007). Also Emerenini et al. (2013) found it as dominant LAB from fresh fruits and vegetables in Nigeria.

Isolates series $\mathrm{B}$ and $\mathrm{C}$ include P.pentosaceus and La. plantarum obtained from day 7. After 2 weeks on day 14 (series D and E), the highest diversity of bacteria covering 
TABLE 2. PHYSIOLOGICAL AND BIOCHEMICAL CHARACTERISTICS OF THE LAB ISOLATED FROM WINTER SALAD

\begin{tabular}{|c|c|c|c|c|c|c|c|c|c|c|}
\hline Group number & 1 & 2 & 3 & 4 & 5 & 6 & 7 & 8 & 9 & 10 \\
\hline Number of strains & 22 & 7 & 11 & 17 & 51 & 9 & 8 & 2 & 5 & 4 \\
\hline Growth at $10 \mathrm{C}$ & + & + & + & + & - & - & + & + & + & + \\
\hline Growth at $45 \mathrm{C}$ & - & $(5 / 2)$ & $(8 / 3)$ & + & $(6 / 45)$ & - & - & - & + & + \\
\hline Growth at $\mathrm{pH}=4.4$ & + & - & - & $(6 / 11)$ & + & + & $(2 / 6)$ & - & + & + \\
\hline Growth at $\mathrm{pH}=9.6$ & $(3 / 19)$ & + & + & - & - & - & - & - & + & + \\
\hline Growth at $6.5 \% \mathrm{NaCl}$ & $(20 / 2)$ & - & - & $(7 / 10)$ & + & + & $(1 / 7)$ & - & + & + \\
\hline Arginine hydrolysis & - & + & + & + & + & + & - & - & + & + \\
\hline $\mathrm{CO}_{2}$ from glucose & - & + & + & + & - & - & + & + & - & - \\
\hline Glucose & + & + & + & + & + & + & + & + & + & + \\
\hline Sucrose & + & + & + & + & - & + & + & + & - & + \\
\hline Galactose & + & + & + & - & + & + & - & + & + & + \\
\hline Fructose & + & + & - & + & + & + & + & + & + & + \\
\hline Lactose & - & + & + & - & + & - & - & + & + & + \\
\hline Maltose & + & + & + & + & + & + & + & + & - & + \\
\hline Sorbitol & + & - & - & - & - & - & - & - & - & - \\
\hline Raffinose & + & $(1 / 6)$ & - & $(2 / 15)$ & - & - & - & - & + & - \\
\hline Manitol & + & - & $(6 / 5)$ & - & - & - & + & + & $(4 / 1)$ & + \\
\hline Mellibiose & + & + & + & - & - & - & - & + & - & - \\
\hline
\end{tabular}

+, all strains positive; -, all strains negative; (.....), number of positive/negative strains. $L A B$, lactic acid bacteria. six species, La. plantarum, La. fermentum, P. pentosaceus, En. faecium, Le. mesenteroides subsp. mesenteroides and W. cibaria, was obtained and La. plantarum was dominant in this period. Three species, P. pentosaceus, La. plantarum and En. faecium, were LAB on day 21 (series F and G). $P$. pentosaceus was predominant $\mathrm{LAB}$ at this period, and this domination continued on day 28 so that six strains of seven identified strains on this day (series $\mathrm{H}$ and $\mathrm{I}$ ) belonged to this species, and the other was En. faecalis.

Lactobacillus and Leuconostoc spp. and in the low rate Pediococcus spp. are found on plants (Stiles and Holzapfel 1997); in this study, these genera with Weissella were found on raw materials. At first, heterofermentative strains such as Weissella and Leuconostoc strains began the fermentation with gas production. Absence of Leuconostoc in the other interval times except for one case may be due to decreased $\mathrm{pH}$ because these species are nonacidophilic and prefer an initial medium pH of 6.5 (Schleifer 2009).

During the fermentation process, heterofermentative strains were gradually replaced by homofermentative strains. The closest product to winter salad with identified LAB is Kimchi, a Korean fermented vegetable food; LAB mostly found in Kimchi fermentation belong to genera Weissella, Leuconostoc and Lactobacillus and to a lesser extent Pediococcus and Enterococcus (Choi et al. 2002; Lee et al. 2002, 2005; Kim and Chun 2004; Cho et al. 2006; Park et al. 2010), but the interesting point in this study is that the P. pentosaceus with $51.1 \%$ was dominant among total LAB. A study on caper berries has obviously shown that in the early stages of fermentation, Pediococccus spp. was predominant but after that Lactobacillus spp. overcame )Perez Pulido et al. 2005). As mentioned in this study, contrary Pediococccus are overpowered on the other genera.

$P$. pentosaceus is involved in many plant fermentation, and during fermentation this product was ubiquitous, probably due to the high salt tolerance and its compatibility with acidic conditions (Daeschel et al. 1987; Schleifer 2009). Singh and Ramesh (2008) also found that Lactobacillus and Pediococcus were the dominant genera after $36 \mathrm{~h}$ of cucumber fermentation.

The isolates and related reference strains were used to construct the phylogenetic tree (Fig. 2). To facilitate, after sequences alignment, only one of the quite similar isolates was chosen to draw the phylogenetic tree. Tree mainly composed of four clusters and six subclusters including eight genera. Cluster I was the Pediococcus group that was composed of two subclusters: subcluster i P. pentosaceus and subcluster ii La. plantarum. Cluster II (subcluster iii) was La. fermentum. Cluster III (subcluster iv) was Enterococcus group. Cluster IV was Leuconostoc group that was composed of two subcluster including subcluster v, the W. cibaria, and subcluster vi, the group of Leuconostoc.

\section{CONCLUSIONS}

Results showed that, in early fermentation period, LAB attended as part of the vegetables microbial population. Twenty-one-day fermentation period brought about a reduction in $\mathrm{pH}$, and an increase in the useful acid lactic microflor that lasted to the end. In the molecular determination phase, selected isolates were strains of LAB that are dominant species during the winter salad fermentation. This type of fermented 
TABLE 3. IDENTIFICATION OF LACTIC ACID BACTERIA ISOLATES FROM WINTER SALAD

\begin{tabular}{|c|c|c|c|c|}
\hline Code of isolate & Day of sampling & Closest strain in NCBI database & Accession number & Percentage similarity (\%) \\
\hline A5 & 0 & Weissella cibaria II-I-59 & NR_036924.1 & 100 \\
\hline A6 & 0 & W. cibaria II-I-59 & NR_036924.1 & 100 \\
\hline A12 & 0 & Leuconostoc citreum KM20 & NR_074694.1 & 99 \\
\hline A13 & 0 & W. cibaria II-I-59 & NR_036924.1 & 100 \\
\hline A25 & 0 & Lactobacillus plantarum WCFS1 & NR_075041.1 & 99 \\
\hline A34 & 0 & Pediococcus pentosaceus ATCC 25745 & NR_075052.1 & 97 \\
\hline A42 & 0 & Weissella cibaria II-I-59 & NR_036924.1 & 100 \\
\hline B11 & 7 & P. pentosaceus ATCC 25745 & NR_075052.1 & 99 \\
\hline B22 & 7 & P. pentosaceus ATCC 25745 & NR_075052.1 & 99 \\
\hline B23 & 7 & La. plantarum PD412 & AB854180.1 & 99 \\
\hline B73 & 7 & La. plantarum WCFS1 & NR_075041.1 & 99 \\
\hline C1 & 7 & P. pentosaceus ATCC 25745 & NR_075052.1 & 99 \\
\hline$C 2$ & 7 & P. pentosaceus ATCC 25745 & NR_075052.1 & 100 \\
\hline C5 & 7 & P. pentosaceus ATCC 25745 & NR_075052.1 & 99 \\
\hline C14 & 7 & P. pentosaceus ATCC 25745 & NR_075052.1 & 99 \\
\hline C33 & 7 & P. pentosaceus ATCC 25745 & NR_075052.1 & 98 \\
\hline D2 & 14 & La. fermentum IFO 3956 & NR_075033.1 & 98 \\
\hline D7 & 14 & La. plantarum WCFS1 & NR_075041.1 & 99 \\
\hline D14 & 14 & La. fermentum IFO 3956 & NR_075033.1 & 98 \\
\hline D18 & 14 & P. pentosaceus ATCC 25745 & NR_075052.1 & 100 \\
\hline D40 & 14 & W. cibaria II-I-59 & NR_036924.1 & 100 \\
\hline D46 & 14 & $\begin{array}{l}\text { Le. mesenteroides subsp. } \\
\text { mesenteroides ATCC } 8293\end{array}$ & NR_074957.1 & 97 \\
\hline D47 & 14 & La. plantarum WCFS1 & NR_075041.1 & 97 \\
\hline D60 & 14 & P. pentosaceus ATCC 25745 & NR_075052.1 & 99 \\
\hline E1 & 14 & La. plantarum WCFS1 & NR_075041.1 & 99 \\
\hline E3 & 14 & La. plantarum WCFS1 & NR_075041.1 & 99 \\
\hline E5 & 14 & Enterococcus faecium Aus0004 & NR_102790.1 & 97 \\
\hline E7 & 14 & La. fermentum IFO 3956 & NR_075033.1 & 98 \\
\hline F5 & 21 & La. plantarum PD412 & AB854180.1 & 99 \\
\hline F43 & 21 & P. pentosaceus ATCC 25745 & NR_075052.1 & 99 \\
\hline F45 & 21 & P. pentosaceus ATCC 25745 & NR_075052.1 & 99 \\
\hline G1 & 21 & P. pentosaceus FMAC63 & KF_060272.1 & 100 \\
\hline G25 & 21 & P. pentosaceus SPA & KF_562066.1 & 97 \\
\hline G31 & 21 & P. pentosaceus ATCC 25745 & NR_075052.1 & 99 \\
\hline G37 & 21 & P. pentosaceus ATCC 25745 & NR_075052.1 & 100 \\
\hline G38 & 21 & P. pentosaceus ATCC 25745 & NR_075052.1 & 100 \\
\hline G39 & 21 & La. plantarum WCFS1 & NR_075041.1 & 99 \\
\hline G43 & 21 & En. faecium Aus0004 & NR_102790.1 & 97 \\
\hline $\mathrm{H} 4$ & 28 & P. pentosaceus ATCC 25745 & NR_075052.1 & 99 \\
\hline $\mathrm{H} 8$ & 28 & En. faecalis V583 & NR_074637.1 & 98 \\
\hline $\mathrm{H} 11$ & 28 & P. pentosaceus ATCC 25745 & NR_075052.1 & 99 \\
\hline H13 & 28 & P. pentosaceus ATCC 25745 & NR_075052.1 & 100 \\
\hline $\mathrm{H} 17$ & 28 & P. pentosaceus ATCC 25745 & NR_075052.1 & 99 \\
\hline 119 & 28 & P. pentosaceus ATCC 25745 & NR_075052.1 & 99 \\
\hline 121 & 28 & P. pentosaceus wg8 & $J X \_477168.1$ & 100 \\
\hline
\end{tabular}

$\mathrm{NCBI}$, National Center for Biotechnology Information.

products has a wide microbial diversity that originates from natural microbiota presented in the raw vegetable and therefore production of a variety of acids and enzymes, which plays an important role in preservation and development of unique flavor and taste. The data obtained from this work provide useful frame for further studies on antimicrobial activity of $\mathrm{LAB}$, their proteolytic and lipolytic activities, and ability to produce exopolysaccharides. Therefore, these strains could be used in the industry. However, the details of the microbes involved in the fermentation of this product are still unclear. Further investigations are needed to shed light on the microbial dynamics, and the analysis of more winter salad would contribute to a better understanding of the fermentation process. 


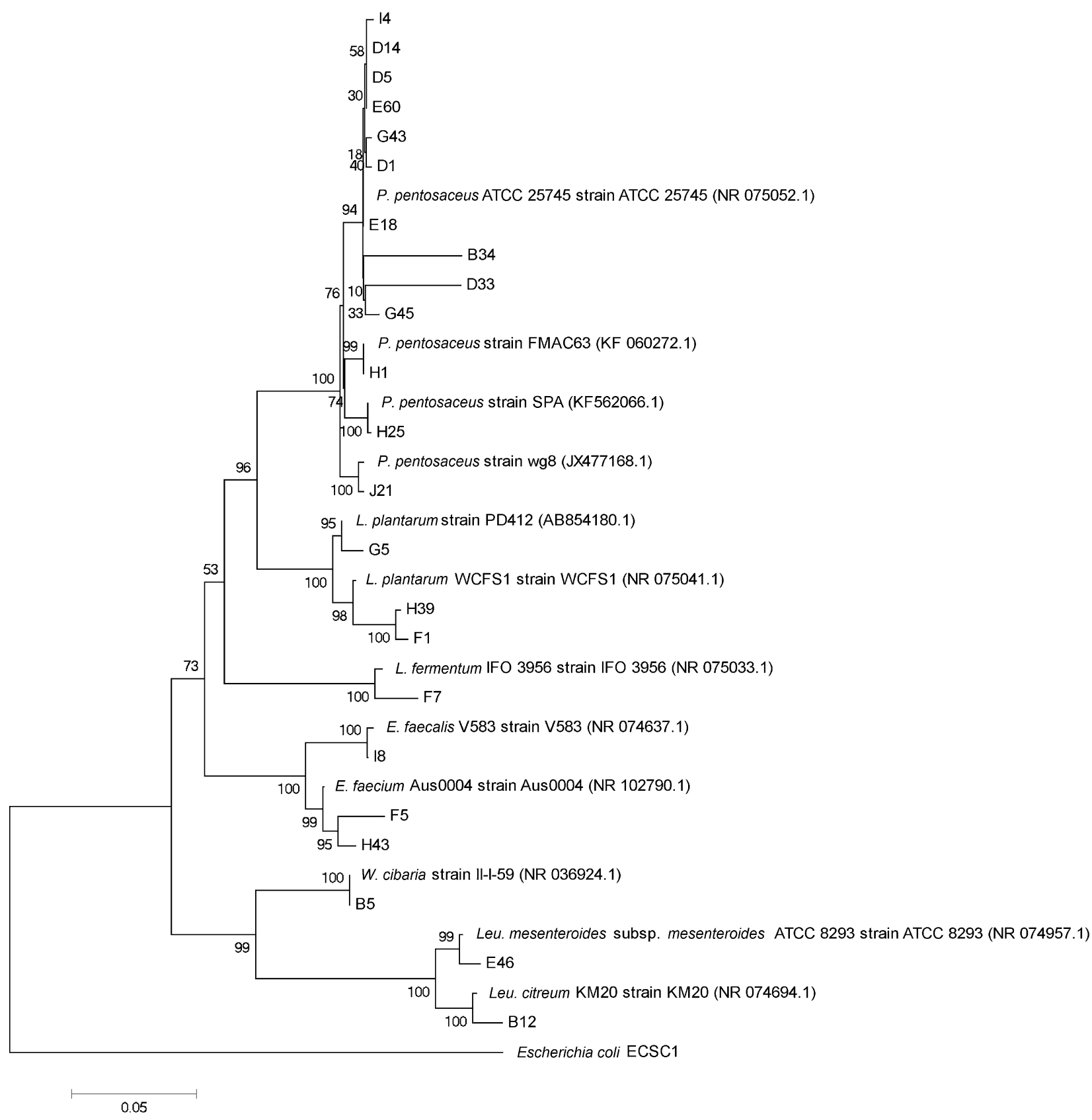

FIG. 2. PHYLOGENETIC TREE BASED ON $16 \mathrm{~S}$ rDNA SEQUENCE ANALYSIS, SHOWING THE PHYLOGENETIC PLACEMENT OF STRAINS ISOLATED FROM WINTER SALAD

The tree was constructed by the neighbor-joining statistical method, and Escherichia coli was used as the outgroup. Bootstrap values for a total of 1,000 replicates are shown at the nodes of the tree. References of the type strains used for comparison are given.

\section{REFERENCES}

ABRIOUEL, H., BEN OMAR, N., COBO, A., CABALLERO, N., FERNANDEZ FUENTES, M.A., PEREZ PULIDO, R. and GALVEZ, A. 2012. Characterization of lactic acid bacteria from naturally-fermented Manzanilla Alorena green table olives. Food Microbiol. 32, 308-316.
AXELSSON, L. 2004. Lactic acid bacteria: Classification and physiology. In Lactic Acid Bacteria: Microbiological and Functional Aspects (S. Salminen, A.V. Wright and A. Ouwehand, eds.) pp. 19-85, Marcel Dekker Inc., New York, NY.

CHAO, S.H., TOMII, Y., WATANABE, K. and TSAI, Y.C. 2007. Diversity of lactic acid bacteria in fermented brines 
used to make stinky tofu. Int. J. Food Microbiol. 123, 134-141.

CHEN, Y.S., WU, H.C. and YANAGIDA, F. 2010. Isolation and characteristic of lactic acid bacteria isolated from ripe Mulberries in Taiwan. Braz. J. Microbiol. 41, 916-921. CHO, J., LEE, D., YANG, C., JEON, J., KIM, J. and HAN, H. 2006. Microbial population dynamics of kimchi, a fermented cabbage product. FEMS Microbiol. Lett. 257, 262-267.

CHOI, H.J., CHEIGH, C.I., KIM, S.B., LEE, J.C., LEE, D.W., CHOI, S.W., PARK, J.M. and PYUN, Y.R. 2002. Weissella kimchii sp. nov., a novel lactic acid bacterium from kimchi. Int. J. Syst. Evol. Microbiol. 52, 507-511.

DAESCHEL, M.A., ANDERSON, R.E. and FLEMING, H.P. 1987. Microbial ecology of fermenting plant materials. FEMS Microbiol. Rev. 46, 357-367.

DYKES, G.A., BRITZ, T.J. and VON HOLY, A. 1994. Numerical taxonomy and identification of lactic acid bacteria from spoiled, vacuum packaged Vienna sausages. J. Appl. Bacteriol. 76, 246-252.

EMERENINI, E.C., AFOLABI, O.R., OKOLIE, P.I. and AKINTOKUN, A.K. 2013. Isolation and molecular characterization of lactic acid bacteria isolated from fresh fruits and vegetables using nested PCR analysis. Br. Microbiol. Res. J. 3(3), 368-377.

FAKLAM, R.R. and COLLINS, M.D. 1998. Identification of Enterococcus species isolated from human infections by a conventional test scheme. J. Clin. Microbiol. 27, 731-734.

GEISEN, R. and HOLZAPFEL, W.H. 1996. Genetically modified starters and protective cultures. Int. J. Food Microbiol. 30, 315-324.

JUSTE, A., THOMMA, B.P.H.J. and LIEVENS, B. 2008. Recent advances in molecular techniques to study microbial communities in food-associated matrices and processes. Food Microbiol. 25, 745-761.

KIM, M. and CHUN, J. 2004. Bacterial community structure in kimchi, a Korean fermented vegetable food, as revealed by $16 \mathrm{~S}$ rRNA gene analysis. Int. J. Food Microbiol. 103, 91-96.

LEE, J.S., LEE, K.C., AHN, J.S., MHEEN, T.I., PYUN, Y.R. and PARK, Y.H. 2002. Weissella koreensis sp. nov. isolated from kimchi. Int. J. Syst. Evol. Microbiol. 52, 1257-1261.

LEE, J.S., HEO, G.Y., LEE, J.W., OH, Y.J., PARK, J.A., PARK, Y.H., PYUN, Y.R. and AHN, J.S. 2005. Analysis of kimchi microflora using denaturing gradient gel electrophoresis. Int. J. Food Microbiol. 102, 143-150.

MOHANIA, A., NAGPAL, R., KUMAR, M., BHARDWAJ, A., YADAV, M., JAIN, S., MARROTA, F., SINGH, V., PARKASH, O. and YADAV, H. 2008. Molecular approaches for identification and characterization of lactic acid bacteria. J. Dig. Dis. 9, 190-198.

PANAGOU, E.Z., SCHILLINGER, U., FRANZ, C.M.A.P. and NYCHAS, G.J.E. 2008. Microbiological and biochemical profile of cv. Conservolea naturally black olives during controlled fermentation with selected strains of lactic acid bacteria. Food Microbiol. 25, 348-358.

PANG, H., QIN, G., TAN, Z., LI, Z., WANG, Y. and CAI, Y. 2011. Natural populations of lactic acid bacteria associated with silage fermentation as determined by phenotype, $16 \mathrm{~S}$ ribosomal RNA and recA gene analysis. Syst. Appl. Microbiol. 34, 235-241.

PARK, J.M., SHIN, J.H., LEE, D.W., SONG, J.C., SUH, H.J., CHANG, U.J. and KIM, J.M. 2010. Identification of the lactic acid bacteria in Kimchi according to initial and over-ripened fermentation using PCR and 16S rRNA gene sequence analysis. Food Sci. Biotechnol. 19, 541-546.

PATIL, M.M., PAL, A., ANAND, T. and RAMANA, K.V. 2010. Isolation and characterization of lactic acid bacteria from curd and cucumber. Indian J. Biotechnol. 9, 166-172.

PEREZ PULIDO, R., BEN OMAR, N., ABRIOUEL, H., LOPEZ, R.L., CANAMERO, M.M. and GALVEZ, A. 2005.

Microbiological study of lactic acid fermentation of Caper berries by molecular and culture-dependent methods. Appl. Environ. Microbiol. 71(12), 7872-7879.

SCHILLINGER, U. and LUCKE, F.K. 1987. Identification of lactobacilli from meat and meat products. Food Microbiol. 4, 199-208.

SCHLEIFER, K.H. 2009. Family V. Leuconostocaceae fam. nov. In Bergeys Manual of Systematic Bacteriology, Vol 3 (P. de Vos, G.M. Garrity, D. Jones, N.R. Kreig, L. Ludwig, F.A. Rainey, K.H. Schleifer and W.B. Whitman, eds.) pp. 624-634, Springer Dordrecht Heidelberg, New York, NY.

SINGH, A.K. and RAMESH, A. 2008. Succession of dominant and antagonistic lactic acid bacteria in fermented cucumber: Insights from a PCR-based approach. Food Microbiol. 25, 278-287.

STILES, E.M. and HOLZAPFEL, H.W. 1997. Lactic acid bacteria of foods and their current taxonomy. Int. J. Food Microbiol. $36,1-29$.

TAHERI, H.R., MORAVEJ, H., TABANDEH, F., ZAGHARI, M. and SHIVAZAD, M. 2009. Screening of lactic acid bacteria toward their selection as a source of chicken probiotic. Poult. Sci. 88(8), 1586-1593.

TAMANG, B., TAMANG, J.P., SCHILLINGER, U., FRANZ, C.M.A.P., GORES, M. and HOLZAPFEL, W.H. 2007.

Phenotypic and genotypic identification of lactic acid bacteria isolated from ethnic fermented bamboo tender shoots of North East India. Int. J. Food Microbiol. 121, 35-40.

TAMANG, J.P., TAMANG, B., SCHILLINGER, U., FRANZ, C.M.A.P., GORES, M. and HOLZAPFEL, W.H. 2005. Identification of predominant lactic acid bacteria isolated from traditionally fermented vegetable products of the Eastern Himalayas. Int. J. Food Microbiol. 105, 347356. 